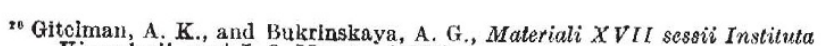
Virusologii, part I, 8, Moscow (1964).

21 Svet-Moldavskiy, G. Ya., Morfologia citopatogennogo deistvia virusov, 101 (Moscow, 1963). 22 Moryon, C., Hsu, K. C., Rifkind, R. A., Knox, A. W., and Rose, H.,
J.Exp. Med.,114, 825 (1001).

23 Hetchin. J. E., Cohen, S. M., Ruska, H., and Ruska, C., Virology, 6, 680
(1958).

Vogt, P. K., and Rubin, H., Virology, 19, 92 (1963).

${ }^{25}$ Vogt, P. K., and Luyex, N., Virology, 20, 75 (1963).

20 Ameno, S., and Ichikava, Y., Fifth Int. Cong. Electr. Microscopy, 2, MM2 (1962) "7 Hubner. R. J., Rowe, W. P., and Lane, W. T., Proe, U.S. Nal. Acald. Sci.,
48, 2051 (1962). 2s Huebner, R. J., Pereira, H. G., Allison, A. C., Hollinehead, A. C., and
'Turner, H. C., Proc. U.S._Nat. Acad. Sci., 5i, 432 (1064).

${ }^{29}$ Van Hooster, G., Stinebaugh, S., and Trentin, J. J., Fed. Proc., 23, N2, 1, 130 (1064).

${ }^{30}$ Knight, C. A., J. Exp. Med., 83, 28 (1946).

"Smith, W., Belyavin, G., and Sheflicld, F. W., Proc. Roy. Soc., B, 143, 504 (1955).

st Kosjakov, P. N., Rovnova, Z. I., and Berłinskich, M. C., \{Tezisi dokladov $X I V$ V sesouznogo syezda epidemiologov, mikrobiologov $i$ infectionistov, 63 (Medicina, Hoseow, 1064).

${ }^{33}$ Smorodincev, A. A., and Korovin, A. A., Gripp, 57 (Moscow, 1961).

${ }^{34}$ Malis, G. V., K etiologii shizofrenii, 182 (Medgiz, Moscow, 1959).

ss Buron, S., Buckler, O. H., and Friedman, R. M., Fed. Proc., 22, 208 (1963).

so Boid, R., Vvedenie $v$ immunochimicheskuju specifichnost, 58 (Moscow, 1963).

"' Knight, C. A., J. Exp. Med., 85, 99 (1947)

Frisch-Niggemayer, W., and Hoyle, L., J. Hygiene, 54, 201 (1958).

${ }^{36}$ Frommhagen, L. I., Knight, C. A., and Friman, N. K., Virology, 8, 176 (1959).

" Zhdanov, V. M., Mekler, L. B., Klimenko, S. M., and Naumova, V. C., Nature, 198, 1326 (1963).

" Kosjakov, P. N., and Rovnova, Z. N., Materiali XVIL sessii Instituta irusolegiz, part 1, 55, Moscow (1064).

12 Kabat, L. A., Blood Group Substances (Academic Press, New York, 1956).

43 Bauer, D. C., Mathies, M. J., and Stavitsky, A. B., J. Exp. Med., 171, 889 (1963).

44 Nezlin, R. C., Biochimia, 39, 548 (1984).

- Rukovodstvo po laboratornoi diagnostike grippa, paragrippoznich $i$ adeno. virusnich zabolevanii. Pod redakciei Gorbmovoi, A. C., i Sokolova, M. I.,
Moscow, Medgiz (1960).
"Hana, T., Styk, B., Rathová, V., and Koxiskova, D., Int. Symp. Nonspecific Resistance to Virus Infection, Interferon and Virus Therapy. Bratislava (1964).

${ }^{47}$ MeDonald, J. C., Brit. Med. J., H, 89 (1962).

-s Zilber, I. A., O prirode virusov, Konferencia, posvachennaa 100-letiju so dnja rozhdenia, Ivanovskogo, D. I., 8, Moscow (1964).

${ }^{49}$ Henle, W., and Deinhardt, F., Proc. Soc. Exp. Biol. and Med., 89, 556 (1955).

${ }^{50}$ Milovanovic, M. V., Enders, J. E., and Mitas, A., Proc. Soc. Exp. Biol. and Med., 85, 120 (ig57).

s1 Russel, P. K., and Morgan, M. R., J. Inf. Dis., 104, 38 (1959).

${ }^{63}$ Bukrinskaya, A. G., and Zhdanov, V. M., Voproci virusologii, N3, 364 (1961).

${ }^{83}$ Lepine, P., Chany, C., Droz, B., and Robbe-Fossat, F., Ann. N.Y. Acad. Sci., 81, part 1, 62 (1959).

${ }^{54}$ Zhdanov, V. M., and Bukrinskaya, A. G., Acta Virologica, 6, 105 (1962).

${ }^{\Delta s}$ Ershov, F. I., Antibiotiki (in the press).

${ }^{58}$ Burnet, M., The Integrity of the Body, 97 (Cambridge, Massachusetts, Harvard University Press; London, Oxford University Press, 1462).

Zhdanov, V. M., Gaidamovich, S. Ya., and Vagzhanova, V. A., Acta Virol., 8, $378(1964)$.

${ }^{88} \mathrm{Kish}$, A. L., and Johnson, K. M., Virology, 16, 177 (1962).

iy Smirnov, L. I., Zhurnal nevrolngii, psichiatrii N11, 831 (1955).

${ }^{\text {вn }}$ Giljarovskii, B. A., Psichiatria, Moscow, 369 (1957).

${ }^{61}$ Roizin, L., Eros, G., and Weinberg, F., Ann. N.Y. Acud. Sci., 96, 477 (1962).

${ }^{62}$ Kuznecova, M. L., and Semenova, C. F., Zhurnal nevrologii, psichiatrii N 6 , 869 (1961).

${ }^{63}$ Bukrinskaya, A. G., Morfologia citopatogennogo deistvia virusov, 18, Moscow (1963).

"Abaumalikova, Z. A., Morfologia citopatogennogo deistvia virusov, 3,

Kingsury, W. W.

Fed. Proc., 23, N 2, 246 (1964).

, Vestnic AMN SSSR, 18, N 5, 68 (1963).

Huebner, R. F., Rowe, W. P., 'Turner, H. C., and Lane, W. T., Proe. U.S. Nat. Acail. Sci., 50, 379 (1903).

${ }^{69}$ Notkins, A. L., and Shochat, S. J., J. Exp. Med., 117, 735 (1063).

${ }^{60}$ Scholtissek, C., and Rott, R., Z. Naturforsch., 166, 863 (1961).

${ }^{70}$ Ginsberg, Y., and Troub, A., Virology, 8, 671 (1059).

${ }^{7}$ Andre, J., and Audebaud, G., Ann. Inst. Pasteur, 98, 820 (1960).

${ }^{2}$ Shelokov, A., Vogel, J, L., and Chi, L., Proc. Sict. Exp. Biol. and Med., 97, 802 (1958).

${ }^{73}$ Lerner, A. M., Cherry, J. D., and Finland, M., Virology, 19, 58 (1963). 34 Beskina, S. R., Ugoleva, N. A., and Shatkin, A. A., Voprosy meditzinskoy
himii (in the press).

${ }^{75}$ Prince, A. M., and Ginsberg, H. S., J. Immunol., 79, 94 (1957).

\title{
OBITUARIES
}

Sir Alwyn Crow, C.B.E.

THE announcement of the death of Sir Alwyn Crow, in Washington on February 5 at the age of seventy, will have been hoard with deep regret by ballisticians and rocketeors in the United States as well as in Great Britain. $\mathrm{He}$ has been describod as a pioneer of rocket design, and there is little doubt that his leadership of the oarly small toams of scientists, first on small solid-fucl rockets and later on guided weapons, laid the first foundations of a modern tochnology and industry which he could scarcely have foreseen.

Alwyn Douglas Crow was born in London on May 10, 1894, and was educated at Westminster School and Quenns' College, C'ambridge. Tho outbreak of the F'irst World War provonted hirr from taking his degreo and he was commissioned in the East Surrey Rogiment in 1914. Ho served until the ond of 1916, when he was invalided, having been gassed and later wounded. He was seconded in 1917 to the Proof and Experimental Dopartment at Woolwich Arsenal. This gave him his introduction to ballisties and, after completing his degroe, ho was appointed the first director of ballistics research at Woolwich, at the early age of twenty-five.

For nearly tho next twenty yoars gun ballistics was to be Crow's subject and much was to be dono to absorb the artillery experioncos of the War; anti-aircraft artillery particularly was in its infancy. His scientific interost was perhaps directed more to the problems of internal ballistics rather than external. Tho subject, largely ompirical, had not received much attention beforo tho early years of the century - the first scientific troatment was by Vielle in 1893 - and modern writings were few. Crow wrote a fow papers on this subject, the best known being those written in collaboration with a colloague, the late W. E. Grimshaw, and published in the Philosophical
Transactions of the Royal Society: "On the Equation of State of Propellant Gases" (1931) and "The Combustion of Colloidal Propellants" (1932). During this time he had created a rescarch team which, although not large was available to meet the challenge of the rocket when it came.

The history of rocket development for military use goes back to Congreve in 1800 , but its popularity as a weapon of war had been spasmodic; no work was in progross after the First World War. However, in 1934 intolligence reports of German developments revived interest in rockets, and after much discussion and preliminury invostigation Crow was appointed in 1936 to form a team to undortake initial examination and research into rockets to meet a variety of possible military requirements. Foremost among theso was anti-aircraft defence. The early designs and initial experiments met with varying degroos of success, but he was not doterred by setbacks and sufficient work was dono to justify the ercation of a Projectile Development Establishment shortly before the beginning of the Second World War of which he was the first chief superintondent. Under the impetus of war a number of investigations were under. taken to meot various suggested applications, but it was some time before rockets went into service, due in part to various disappointments or partial failures. Crow, however, did not lose faith, and, once success was achicved in tho first projects, applications bceame numerous. Bused cssentially on throe rockets of 2-in., 3-in. and 5 -in. calibres some 20 major weapons were produced. Many of these aro now matters of history:-the ' $Z$ '-batteries deployed around London and olsewhere; 3 -in. rockets fired from all types of fighter aircraft for the attack of ground and soa targots; 'Mattress' coast bombardment 5ँ-in. rockots used in Sicily and Normandy. 
Among the early investigations carried out in 1939-40 was one proposed by Lord Cherwell (then Prof. Lindemann) for a guided rocket which could be controlled to attack aircraft. The result of the investigation was that it was possible theoretically, but the then available solid cordite rockets had insufficient power for the task. The idea was shelved. In 1944 when information of German liquid fuel motors was becoming available the idea was revived, and Crow was confident that a guided rocket could be developed to meet the then stated military needs. He had during 1940-45 been controller of projectile development; he was now to become director of guided projectiles.

When the Ministry of Supply and the Ministry of Aircraft Production were amalgamated the research and development of rockets and guided weapons was reorganized and he left this field that had been particularly his own. He then became head of technical services to the British Joint Services Mission in Washington, D.C. Here he was well received, for he had freely exchanged research information with American ballisticians and had supplied large quantities of rockets to them before they had completed developments themselves. He spent seven happy and profitable years in the United States in this liaison post. He retired in 1954 and returned to rocket work as a consultant for firms on both sides of the Atlantic and finally settled in Washington in 1958 .

Sir Alwyn Crow was knighted in 1944 for his services to rocket development, and the United States honoured him with the U.S. Medal of Freedom with Bronze Palm in 1948.

R. C. KNIGHT

\section{Prof. Rudolf Seeliger}

Rudoly Seeliger, the German physicist best known for his work in the field of electric discharges in gases, died after a long illness in Greifswald, Pomerania, on January 20, at the age of seventy-eight. $\mathrm{He}$ was the son of a famous father: Hugo von Seeliger, professor of astronomy in the University of Munich, was one of the first to introduce physics into astronomy.

Rudolf Seeliger, who grew up in the particular atmosphere of Bavarian academic circles of 1900 , studied mathematics and physics and, being a 'travelling scholar', went to the Universities of Tübingen, Heidelberg and finally Munich. There, under the guiding hand of Arnold Sommerfeld, then professor of theoretical physics, he worked on his doctoral thesis, taking his degree in 1920. In it we find a rigorous treatment of the problem of the current-voltage relation pertaining to the ionization chamber with plane parallel plates and filled with a gas at high density: the assumptions were that by irradiating the gas a uniform ionization is produced throughout its volume while the loss of positive and negative ions was taken to be partly due to charge recombination in the gas and partly due to mobility-controlled removal of charges to the electrodes, ion diffusion being neglected. This problem had boen formulated earlier by J. J. Thomson, who gave an approximate solution. Seeliger also extended this investigation to include concentric cylindrical and concentric spherical systems. He spent the following two years with W. Wien, the 1911 Nobel Prize Winner, in the University of Würzburg, assisting him in experiments with positive rays. During 1912-18 he worked at the Physikalisch-Technische Reichsanstalt in Berlin on discharge phenomena. In 1918 he was appointed professor of theoretical physics at Greifswald where he stayed for the rest of his life.

Though trained as a theoretician, Seeliger had always had great flair, interest and skill in experimental physics, but it was only with great reluctance that the director of the Department of Physies and the Senate of the University acceded to Seeliger's wishes to provide space for his own experimental research which ho finally obtained in the basement.
His earlier work was concerned with an investigation of the emission spectrum from the negative zones of a glow discharge. From it he derived what is now known as 'Seeliger's Rule': as one approaches the negative glow from the cathode the sequence of lines in the dark space is such that those lines appear first whose excitation function maximum is at the highest electron energy. It follows that in spite of the increase in potential the electrons coming from the cathode must lose an appreciable amount of energy as they approach the boundary between the dark space and the negative glow, a fact which tallies with the observed decrease in the electric field strength. Later he investigated the transition from the dark to the glow discharge and the properties of a glow discharge at atmospheric pressure. With the advent of the Langmuir probe, he made, for example, simultaneous measurements of the longitudinal electric field in the positive column and of the mean electron energy; he also calculated the charge distribution along the wall of such a column.

He paid particular attention to arc discharges with non-thermionic cathodes, considered field emission and showed the anomalous behaviour of carbon arcs at low gas pressure which suddenly change from the thermionic emission to the non-thermionic vapour mode, a mechanism which only recently has been explained more fully. His work included the examination of certain chemical changes in the gas of discharges and clean-up effects, and he demonstrated that ion impact into glow cathodes largely accounts for the disappearance of the gas by recovering the latter. Another of his research activities was the study of the mechanism of the electric precipitation of dust particles from combustion gases and smoke.

Seeliger was a prolific writer. During 1924-33 he was editor of the Physikalische Zeitschrift; he contributed extensive articles to the Jahrbuch der Radioaktivität, the Handbuch der Radiologie; and he produced the most complete account of discharge physics of the day in the Handbuch der Experimental-Physik. In 1927 he wrote a book for research workers entitled Physik der Gasentladungen and in 1938 one on applied atomic physics designed to bring the fundamentals to modern electrical engineers. He co-operated for many years with industry, particularly with Siemens and Osram. I remember our colloquia at Greifswald and Berlin in the form of exchange visits, the hospitality and kindness with which Seeliger treated not only his colleagues but also his juniors, and his gift for telling good stories. When I last visited him in 1960 , he was still at work in spite of his illness.

After the Second World War Seeliger was elected rector magnificus of his University, director of the Department of Gas Discharge Physies, and a member of the German Academy of Sciences. He received in 1950 the 'Nationalpreis', and in 1956 the Order of Merit of the German Democratic Republic. The Physikalische Gesellschaft made him an Honorary Member and his University an honorary senator.

He was married to Eva, née Lipps, who survives him with three daughters.

A. VON ENGEL

\section{Dr. J. A. Ferrell}

Dr. John A. Ferrell, widely recognized by public health men as the national leader of the county health movement in North America, died on February 18 in Raleigh, North Carolina, following a long illness. Dr. Ferrell, who was eighty-four years old, was associate director of the International Health Division of the Rockefeller Foundation from 1913 until his retirement in 1944 and a central figure in one of the most effective demonstrations of the function of private philanthropy in stimulating the public to meet a social need, in this case for organized rural health survices.

Dr. Ferrell was born in Clinton, North Carolina, on December 14, 1880. He received his bachelor (1902) and 